\title{
Anchored piles in Santiago's gravel: modeling results for displacement curve
}

\author{
Pilotes anclados en grava de Santiago: resultados de modelaciones para la curva de \\ desplazamiento
}

Dennis Raddatz (Main and Corresponding Author)

Ferrara - Proyectos Especiales

Rengo 1270, Ñuñoa, Santiago (Chile)

dennis.raddatz@ferrara.cl

\section{Oscar Taiba}

Ferrara - Proyectos Especiales

Rengo 1270, Ñuñoa, Santiago (Chile)

oscartaiba@ferrara.cl

Manuscript Code: 803

Date of Acceptance/Reception: 03.11.2017/01.09.2016

DOI: 10.7764/RDLC.16.3.457

\begin{abstract}
This study describes the method of discontinuous and anchored machine bored piles. The main advantage of this method is its faster and safer execution in comparison with hand-dug piles (rectangular section), the most widely used method for soil retaining in the gravel of Santiago. This paper shows the results of displacement versus height obtained by a numerical modeling (software Plaxis 2D), in the case of anchored machine bored piles used for the construction of the Faculty of Physical and Mathematical Sciences, Universidad de Chile. As part of monitoring of excavation, measurements of displacements were obtained for two piles at different stages by preinstalled inclinometers in the piles. Furthermore, the study shows the results for the displacement using rod construction module (software GGU-Retain), and through Winkler's theory (software CYPE: Embedded retaining walls), considering the most representative stages and the redistribution of soil pressure that is indicated in the Chilean Norm NCh.3206 for the model done on GGU-Retain. The results of the performed modellings are graphically compared with the measured field values.
\end{abstract}

Key words: Discontinuous bored piles, anchored bored piles, gravel of Santiago, retaining structure, displacements versus depth.

\section{Resumen}

En este estudio se describe el método de entibación de pilotes anclados y discontinuos. La ventaja principal de este método es la mayor rapidez y seguridad en su ejecución en comparación con las pilas ancladas (sección rectangular y excavadas manualmente), método más usado para entibaciones en la grava de Santiago. En este artículo, se entregan los resultados de desplazamiento versus altura obtenidos por medio de una modelación numérica (software Plaxis 2D), para el caso de los pilotes de entibación del edificio de la Facultad de Ciencias Físicas y Matemáticas de la Universidad de Chile. Como parte del monitoreo de la excavación, se realizaron mediciones de desplazamiento en diferentes etapas para dos pilotes, obtenidas por medio de inclinómetros instalados previamente en los pilotes. Además, se incluyen los resultados para el desplazamiento obtenidos usando un sistema de vielas (software GGU-Retain) y un modelo de fuerza-deformación de Winkler (software CYPE: Muros Pantallas), considerando las etapas más representativas y la recomendación de redistribución de empujes de la norma chilena NCh.3206. Los resultados de las modelaciones realizadas son comparados de forma gráfica con los valores medidos en terreno.

Palabras clave: Pilotes discontinuos, pilotes anclados, grava de Santiago, estructura de contención, desplazamiento versus profundidad.

Introduction

In urban zones it is usually not possible to use non-vertical slopes to retain an excavation due to the limited space (Abramson, Lee, Sharma, \& Boyce, 2002), so a vertical support is needed. For a discontinuous bored piles screen the typical free space between piles is three times the width (for hand-dug piles) or diameter (for machine bored piles). The retaining of the soil between piles is possible because the arc effect.

For purposes of this article the word "hand-dug pile" is used to refer to the structural element of rectangular section, made of reinforced concrete and excavated manually. The word "pile" refers to the element of circular section, made of reinforced concrete and mechanically drilled.

The most used method in Santiago to support deep and temporary excavations is anchored hand-dug piles, located discontinuously (Saez \& Ledezma, 2012). In recent years, the use of anchored piles has been incorporated, fulfilling the same function of hand-dug piles. 
This article describes the method of anchored piles as a soil retaining system, and the characteristics of the new Engineering Building School of Universidad de Chile, where a deep excavation was necessary and the method of discontinuous anchored piles was used. On the other hand, a study of the geotechnical and structural parameters of the project located in downtown Santiago was conducted, in order to build models for a numerical analysis through the software Plaxis 2D, GGU-Retain and CYPE: Embedded retaining walls. In addition from this excavation, pile displacement measurements were taken at different stages of the excavation as part of the monitoring program financed and performed by IDIEM (Investigación, Desarrollo e Innovación de Estructuras y Materiales), research and development center dependent of Universidad de Chile.

Finally, the results of modeling and a comparison with the values measured on site are shown.

\section{Description of anchored discontinuous pile walls}

Retaining walls are structures supporting soils with steep slopes, which can be vertical (Terzaghi, Peck, \& Mesri, 1996). Among the types of retaining walls it is possible to identify anchored and discontinuous piles or hand-dug piles.

Piles are constructed by digging a hole in the ground (Candogan, 2009), installing a rebar frame inside, and pouring concrete from the surface. During the excavation a steel casing can be used to avoid the collapse of the walls on the hole, and it is also used as a guide in the drilling process (Kempfert, Dieter, \& Smoltczyk, 2003).

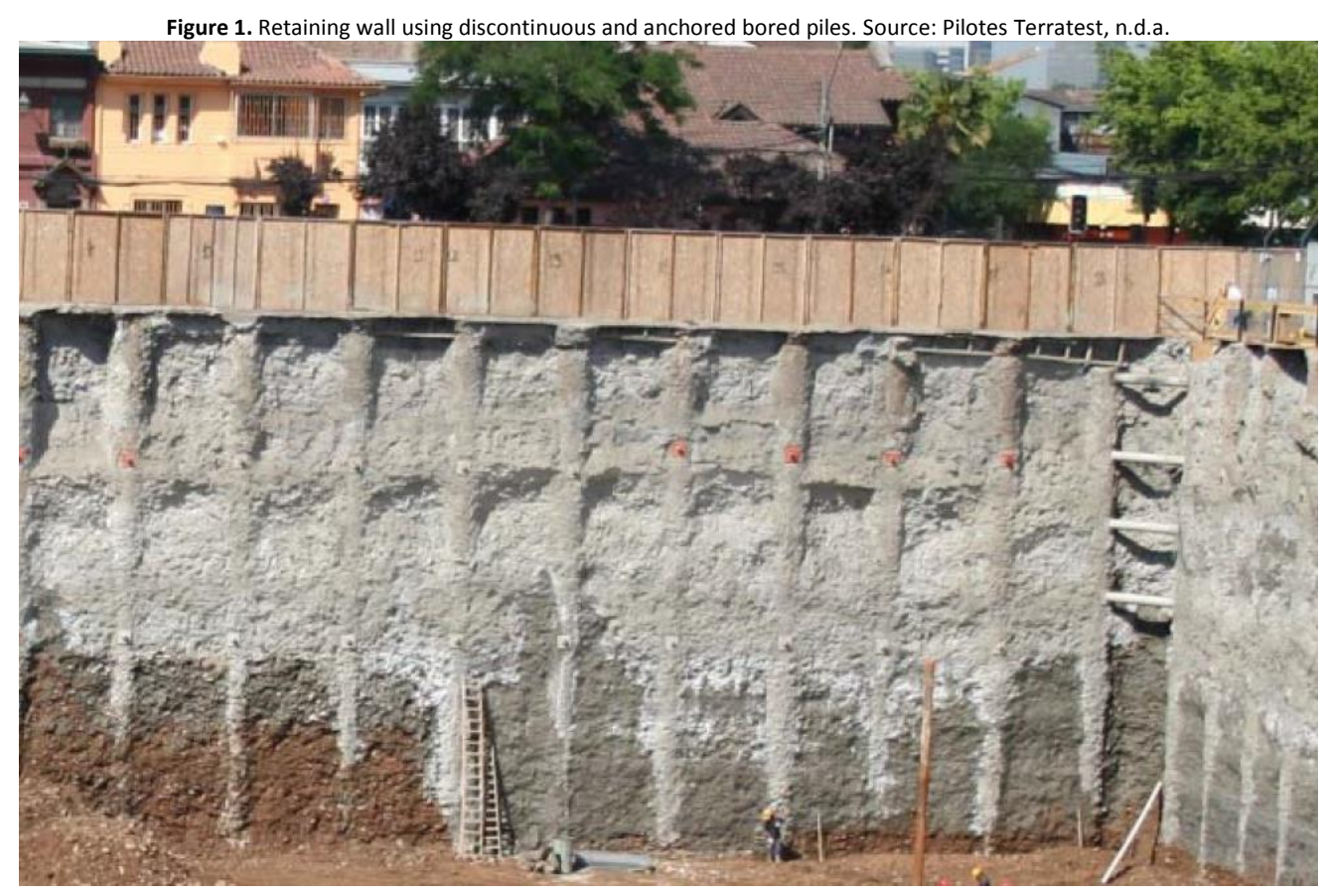

One of the advantages of using bored piles in comparison with driven piles is that no important vibrations are generated (Weissenbach, Hettler, \& Simpson, 2003), and that greater excavation depths can be reached. In comparison to handdug piles the main advantage of bored piles is related to safety. The drilling of hand-dug piles is done manually, taking workers into the holes, which can be very deep, exposing them to collapses from the walls of the excavation resulting from local instabilities, vibrations in the surface or earthquakes. Moreover, workers are exposed to be hit by heavy objects accidentally dropped into the hole from the surface, or to falls during their ascent or descent within the hole. In the case of using piles, all the drilling process is performed from the surface. Another advantage of using piles is the installation of a rebar frame, which is prepared on the surface level and placed into the hole by using cranes, so that the compliance with the provisions of longitudinal and transverse reinforcements can be reviewed by qualified personnel. Meanwhile, for hand-dug piles, in most cases the reinforced steel cage is placed directly into the hole, making revision difficult.

Among the disadvantages of using piles it can be mentioned that the structural elements (hand-dug piles and piles) act primarily though flexion (Coduto, Yeung \& Kitch, 2011). The circular section of a pile is less efficient than the rectangular section of a hand-dug pile, where all the longitudinal steel reinforcement can be placed furthest from the center line. Conversely, in piles the longitudinal steel is evenly distributed on the perimeter, placing bars in the vicinity of the neutral 
axis. Another disadvantage is economic; since the linear meter of excavation of bored piles is considerably more expensive than using personnel for manual digging.

Once piles are built and when the concrete reaches enough strength, the excavation in front of them can be started. Anchors can be used to reduce the movement of the screen; their feasibility in the desired depth will depend on the type of neighbor structure present (Puller, 2003). The anchors are made of steel, they are tightened and the force is transferred to the ground through its fixed length (Ostermayer \& Barley, 2003). The anchors must work successfully during its operation time, so protection against corrosion should be considered, in addition to field tests using loads exceeding the service load.

\section{School of Engineering Building Project- Universidad de Chile}

\section{Project Description}

The new building of the faculty of physical and mathematical sciences at Universidad de Chile, is located between the streets Beauchef, Club Hípico, Blanco Encalada and Tupper, in Santiago commune, Metropolitan Region (Pilotes Terratest, n.d.b). The building has seven floors and six underground levels, its building foundation level is $-27.5 \mathrm{~m}$ or $29.0 \mathrm{~m}$ depth from project zero line, which is located close to the natural ground level of the sector.

In total the building has more than $50,000 \mathrm{~m}^{2}$ of constructed surface (FCFM, 2011). The entire construction project and the materials used incorporate the concept of sustainability, reducing the pollution generated in each of the stages, and using recyclable materials. The architectural design is especially suited to the use of natural light in order to reduce the use of artificial light; and solar panels are implemented for hot water supply.

\section{Piles and Anchors}

Retaining project was calculated and executed by the company Pilotes Terratest. $1.00 \mathrm{~m}$ diameter piles were considered in the perimeter where there was enough space for their installation, located on plant every $2.50 \mathrm{~m}$ between piles axis (where building foundation level was located at $-29.00 \mathrm{~m}$ depth) or $2.95 \mathrm{~m}$ between piles axis (where building foundation level was located at $-\mathbf{2 7 . 5 0} \mathrm{m}$ depth). On the north limit there was an existing University building, without enough space for pile installation because pile machines does not fit due to the existing building, then rectangular handdug piles were placed under existing foundations of that building as underpinning piles.

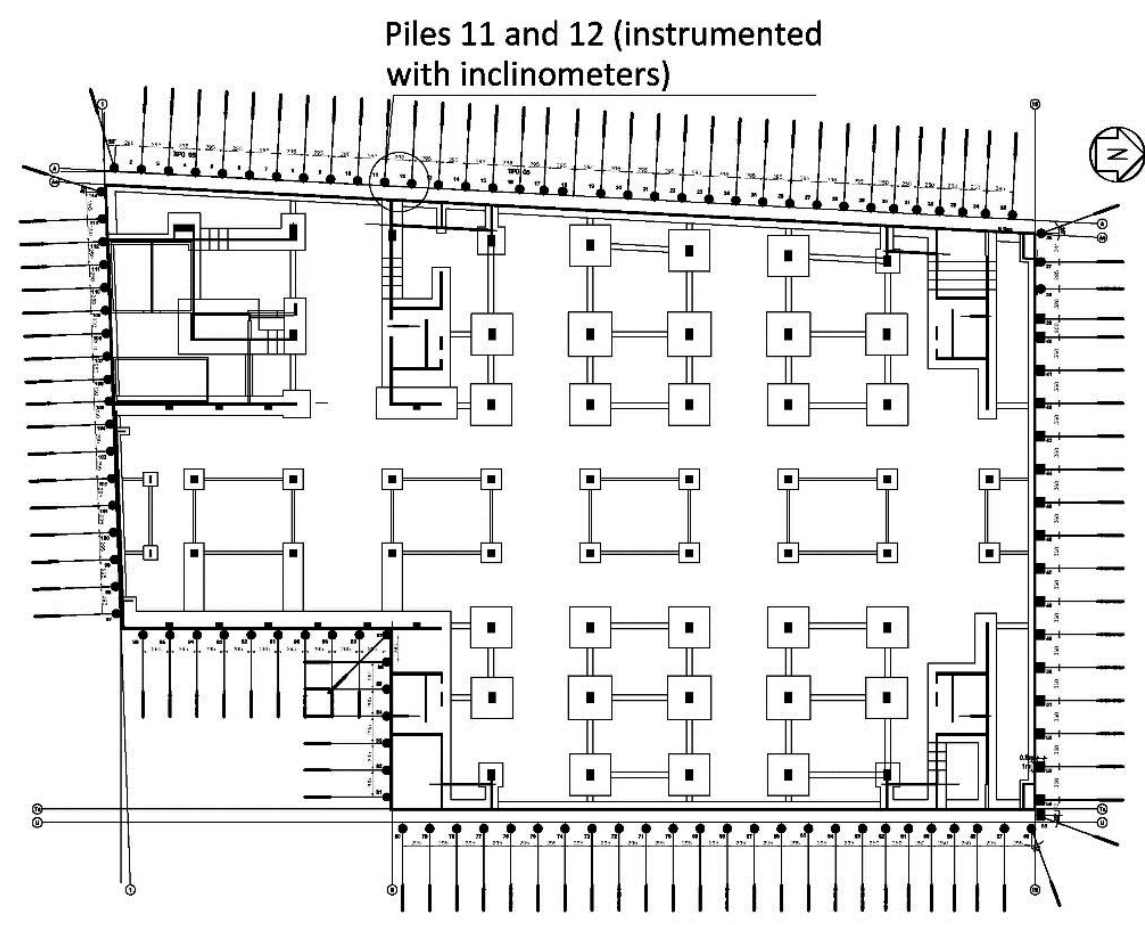


Piles considered $2.5 \mathrm{~m}$ of embedment; meaning that level of pile toe was $-30.00 \mathrm{~m}$ or $-31.50 \mathrm{~m}$. The pile head level was considered at elevation $-1.50 \mathrm{~m}$ in order to meet some municipal ordinances, using minor slopes from the pile head to the soil surface. Anchors of steel cables were used as lateral bracing elements; each cable having a yield force of $235 \mathrm{kN}$ and a diameter of 0.6 inches. The amount of cables depended on the service load of the anchors.

Inclinometers were installed in two piles, with the purpose to measure displacement in different stages (Rozic, 2012). The piles instrumented with inclinometers were positioned in area with pile separation of $2.95 \mathrm{~m}$ between piles axis where building foundation level was $-27.50 \mathrm{~m}$. Measurements were recorded in stage two (before the installation of first anchor line), stage four (before the installation of second anchor line), stage five (after installation and tensioning of the second anchor), stage six (before the installation of third anchor line), and stage eight (final stage of excavation). Measurements of pile 11 were available for this work. For fixed lengths of anchors it was used a ground to grout pull out reduced resistance of $250 \mathrm{kN} / \mathrm{m}$, this value is typically used on all projects located where the gravel of Santiago is present. The structural properties of piles and anchors in the area where displacement measurements were recorded are shown below:

Table 1. Properties of the Piles. Source: Prepared by the authors, 2015.

\begin{tabular}{ll}
\hline Properties & Value \\
\hline Length $[\mathrm{m}]$ & 28.5 \\
Diameter $[\mathrm{m}]$ & 1.0 \\
Elastic Modulus $\left[\mathrm{KN} / \mathrm{m}^{2}\right]$ & $23,875,200$ \\
Cross sectional area $\left[\mathrm{m}^{2}\right]$ & 0.7854 \\
Area moment of Inertia $\left[\mathrm{m}^{4}\right]$ & 0.049 \\
Axial stiffness $[\mathrm{KN}]$ & $18,751,540$ \\
Flexural stiffness $\left[\mathrm{KN}^{*} \mathrm{~m}^{2}\right]$ & $1,169,884$ \\
\hline
\end{tabular}

Table 2. Properties of the anchors. Source: Prepared by the authors, 2015

\begin{tabular}{llll}
\hline Properties & First & Second & Third \\
\hline Depth [m] & -5.00 & -13.00 & -21.00 \\
Free length [m] & 16.1 & 12.8 & 7.9 \\
Fixed length [m] & 4.1 & 5.2 & 5.4 \\
Service load [KN] & 1,004 & 1,297 & 1,331 \\
Free length stiffness [KN] & 191,100 & 245,700 & 245,700 \\
Fixed length stiffness [KN] & 307,500 & 390,000 & 390,000 \\
\hline
\end{tabular}

This project is placed on the typical gravel of Santiago, which has been deeply studied. The high values of cohesion for gravel are justified on previous analysis of triaxial results on this soil (Ortigosa \& Hidalgo, 1997). Also, two layers of fine soil identified in soil mechanics report have been considered on the models made by Pilotes Terratest on the design of the piles (Pilotes Terratest, 2011). The fine soil layers were considered on all numerical models done for this research project.

Table 3. Properties of Soil. Source: Prepared by the authors, 2015.

\begin{tabular}{|c|c|}
\hline \multirow[t]{4}{*}{ Layer 1 (0 to $6.5 \mathrm{~m}$ depth) } & - Fluvial gravel: Second deposit. \\
\hline & - Internal friction angle $=45^{\circ}$ \\
\hline & - Cohesion $=23.0 \mathrm{kN} / \mathrm{m}^{2}$ \\
\hline & - Unit weight $=22.0 \mathrm{kN} / \mathrm{m} 3$ \\
\hline \multirow[t]{4}{*}{ Layer 2 (From 6.5 m depth) } & - Fluvial gravel: First deposit. \\
\hline & - Internal friction angle $=45^{\circ}$ \\
\hline & - Cohesion = $35.0 \mathrm{kN} / \mathrm{m}^{2}$ \\
\hline & - Unit weight $=23.0 \mathrm{kN} / \mathrm{m3}$ \\
\hline \multirow{4}{*}{$\begin{array}{l}\text { Interlayer (From } 21.0 \text { to } 22.0 \text { and } \\
\text { from } 26.0 \text { to } 27.0 \mathrm{~m} \text { depth) }\end{array}$} & - Fine Soil: Interlayer. \\
\hline & - Internal friction angle $=26^{\circ}$ \\
\hline & - Cohesion $=55.0 \mathrm{kN} / \mathrm{m}^{2}$ \\
\hline & - Unit weight $=18.0 \mathrm{kN} / \mathrm{m} 3$ \\
\hline
\end{tabular}


A background review for the gravel of Santiago was done, and for the deformation modulus an expression that increases with depth was adopted, with " $z$ " depth in meters.

$$
E=45000 \sqrt{z}\left[K N / m^{2}\right]
$$

This equation is similar to that used by many experts in Santiago based on the work of Ortigosa and Kort (1997), where the relationship between deformation modulus and depth it was found through plate bearing load test at different depths. Satisfactory modeling results were obtained with this formula, specifically preventing displacement in the embedment length of piles for the final stage of excavation, as it happens with the field measurements.

Numerical analysis

In this section the numerical analysis performed with the computer programs Plaxis 2D, GGU-Retain and CYPE: Embedded retaining walls are described. The analysis was performed by stages in order to represent properly the problem. An analysis of static pressure was conducted at each stage, with the exception of the addition of seismic increase between stages two and four, as when comparing the dates of these measurements (between March 4th and April 3rd, 2010 respectively) and the records of major earthquakes in Chile, it was found that on March 10th, three strong after-shocks of the earthquake of February 27th, 2010 occurred. Two of the aftershocks had epicenter in Pichilemu (magnitude 6.0 and 6.9 MW), and the other one had epicenter in La Estrella (magnitude 6.7 MW). Even though there were other aftershocks that exceeded 6.0 MW between the different stages, the three considered were strongly felt in Santiago due to the closeness of the epicenters. In order to simplify the seismic influence a horizontal acceleration of $0.15 \mathrm{~g}$ to calculate seismic increase was considered throught a Mononobe Okabe method (Towhata, 2008).

Since the construction area is surrounded by streets, a surface overload of $12.0\left[\mathrm{KN} / \mathrm{m}^{2}\right]$ was adopted as it is indicated in the Chilean design code NCh3206 (INN, 2010).

\section{Plaxis 2D}

The program of finite elements Plaxis 2D was used to model each stage of the excavation under study. The option of plain strain model was used because the uniformity in the cross section. The option of plate type elements was used for piles, and the node to node anchor option plus a geogrid element were used for anchors. The properties of the elements were used in units per linear meter. Then, the discontinuous system (discontinuous piles) is modeled as a continuous system with equivalent rigidity per linear meter. This is a reasonable approximation for analyzing of this kind of problems (Tsui \& Clough, 1974).

The hardening soil model was used for the soil (Brinkgreve, 2014). The necessary parameters to model soil behavior with this model are: secant stiffness in standard drained triaxial test $\left(E_{50}\right)$, tangent stiffness for primary oedometer loading $\left(E_{o e d}\right)$, and the unloading / reloading stiffness ( $\left.E_{u r}\right)$. The average value of elastic modulus of the soil was considered as the secant or tangent stiffness.

$$
E \approx E_{50} \approx E_{\text {oed }}
$$

Approximately, below formula was used (Brinkgreve, 2014):

$$
E_{u r} \approx 3 * E_{50}
$$

Several layers for gravel were used on the model, each with the parameters according to soil mechanics report and with only one value of stiffness assigned, an average based on mentioned equation for deformation modulus.

For the seismic load increment during stage 2, the recommendations of Seed \& Whitman (1970) were followed throught a pseudo dynamic analysis. Based on studies of several authors, they suggest using the results of the seismic increase at $0.67 \mathrm{H}$ from the bottom of the excavation, with $\mathrm{H}$ the free height of the wall. This is equivalent to using the inverted triangle. 


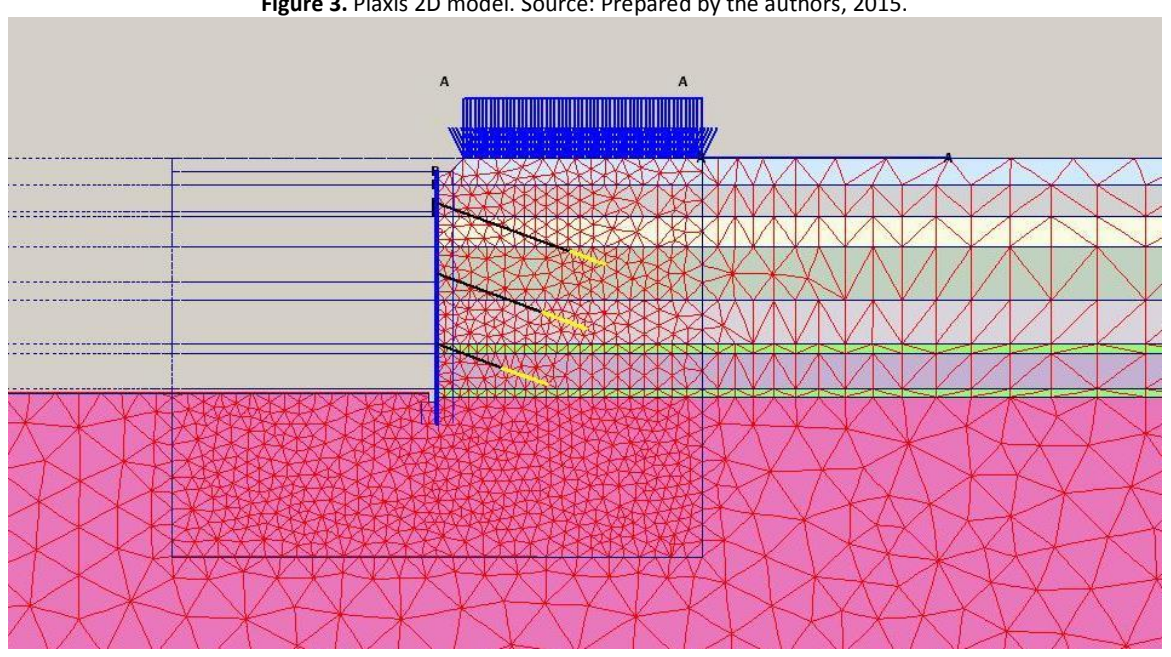

\section{GGU-Retain}

Another computer program used was GGU-Retain, which does not model the pile as a beam, but it utilizes a system of rod construction module that treats the screen of piles and the anchors as a single structural system (Civilserve Gmbh, 2007). To calculate soil pressure, a weighing between active pressure (66.6\%) and at rest pressure (33.3\%) was considered. Weissenbach and colleagues (2003) recommend using a pressure exceeding the active pressure when there is restriction in deformation. In this case there are piles of $1.0 \mathrm{~m}$ diameter, with spacing between piles axis of $2.95 \mathrm{~m}$, so the stiffness of the elements would not allow the development of full active pressure. The partial development of active pressure it was successful used on another calibration of field measurement with a numerical model on a retaining wall (Raddatz, Suazo \& Taiba, 2016). As pointed out by Chilean Norm NCh3206 (INN, 2010) a uniform distribution was adopted for pressure redistribution. For the friction angle between pile and soil, $2 / 3 \varphi$ was considered, with $\varphi$ the angle of internal friction of the soil, as recommended for this kind of structural elements (DGGT, 2014).

The most characteristic stages were modeled according to the directions provided in the program (Civilserve Gmbh, 2007). The deformations at anchor levels of the previous stage were entered in the analyzed stages.

Figure 4. GGU-Retain model. Source: Prepared by the authors, 2015

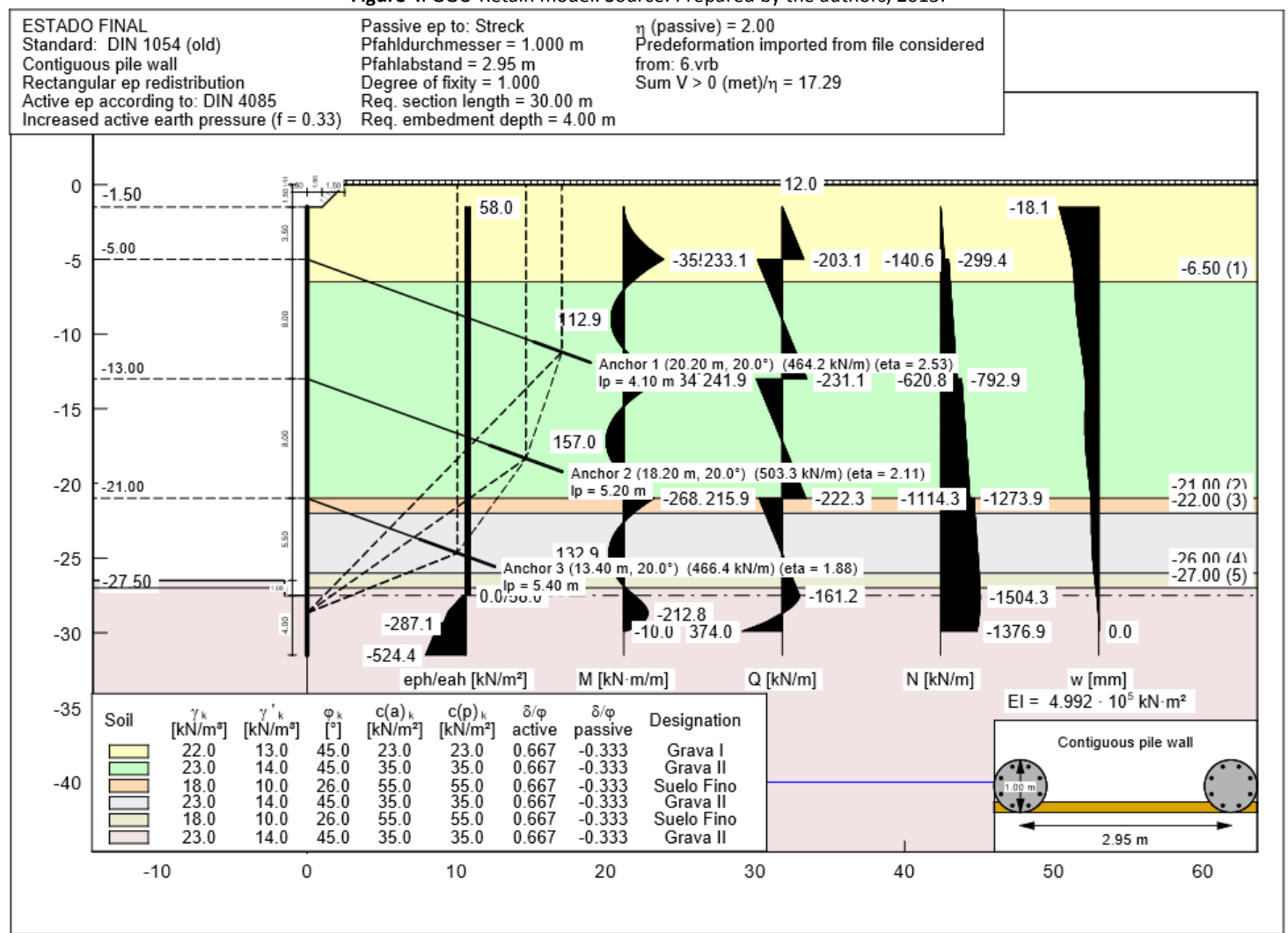




\section{CYPE: Embedded retaining walls}

Finally, the software Cype: Embedded retaining walls was used to model the excavation. This software uses Winkler's theory with pressure-deformation relationship as elastoplastic behavior and modeling springs through the subgrade modulus coefficients (Cype Ingenieros, n.d.). Lateral pressure on the wall are never lower than the active pressure and never higher than passive pressure. If the displacement is zero, then the pressure is equal to at-rest pressure. The displacement and pressure on the wall are obtained after convergence of results with iterations and considering the results of the previous stage.

Figure 5. CYPE model. Source: Prepared by the authors, 2015.

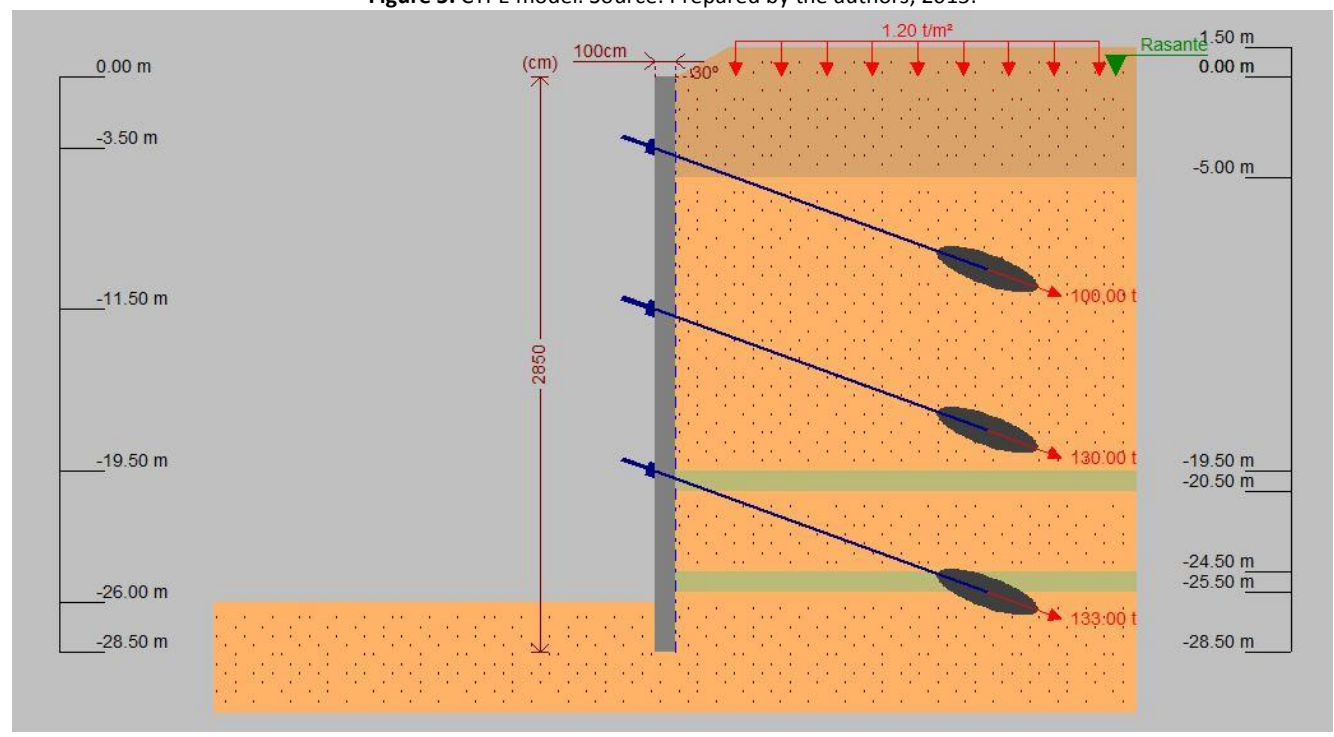

All stages were modeled with the same soil parameters used on GGU-Retain. The subgrade modulus coefficients were obtained with the Chadeisson chart and suggestions indicated on the software, $100,000 \mathrm{kN} / \mathrm{m}^{3}$ for second deposit of gravel, $130,000 \mathrm{kN} / \mathrm{m} 3$ for first deposit of gravel and $30,000 \mathrm{kN} / \mathrm{m} 3$ for the interlayers of fine soil.

\section{Results and Discussion}

The following figures show graphically the comparison between field measurements and results of numerical modeling. Graphs correspond to stage four (before the installation of the second anchor line), six (before the installation of the third anchor line), and eight (final state of excavation). The first data recorded on the field was on stage two, then all model results consider the subtraction of displacement of stage 2 .

Figure 6. Comparison between measurements and modeling results for stage 4 (before the installation of second anchor line). Source: Prepared by the authors, 2015. 


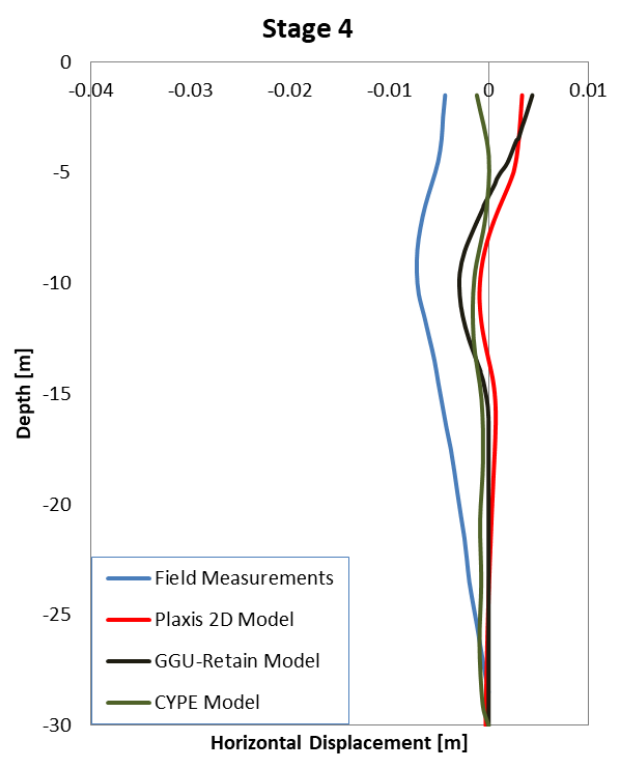

Figure 7. Comparison between measurements and modeling results for stage 6 (before the installation of third anchor line). Source: Prepared by the authors, 2015.

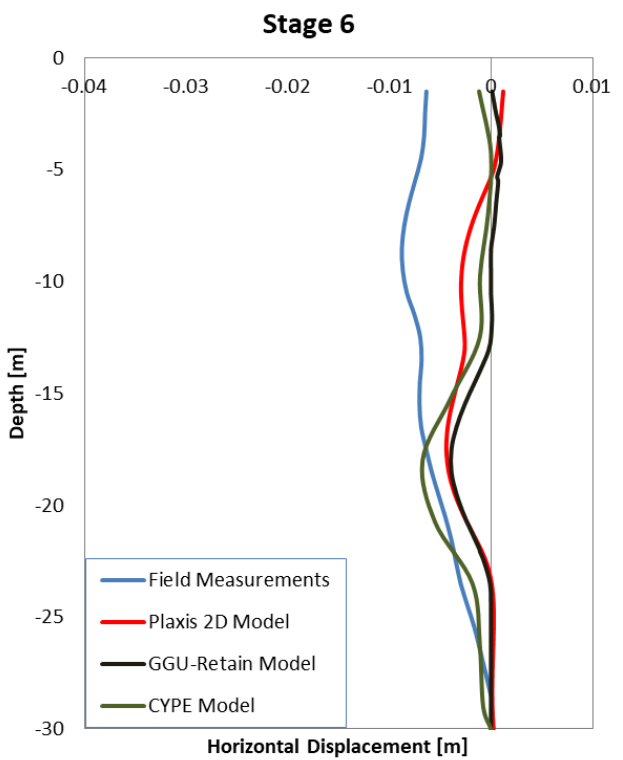

Figure 8. Comparison between measurements and modeling results for stage 8 (final stage of excavation). Source: Prepared by the authors, 2015. 


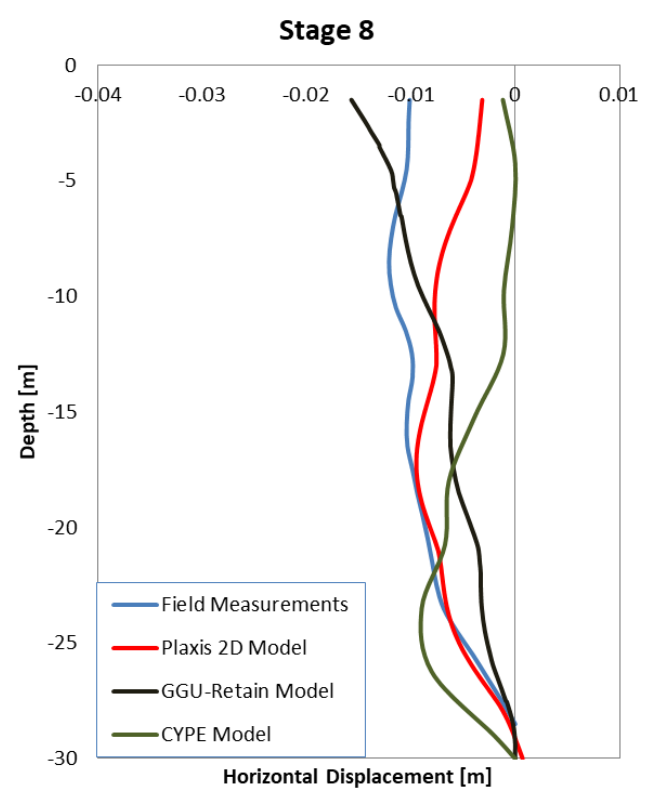

The graphs shows that the results obtained from modeling are in the same order of magnitude as the field data, but field measurements have a greater displacement in the upper part of the pile, developed importantly at an early stage of the excavation (stage 4).

The graph obtained from GGU-Retain model is similar to the graph obtained from Plaxis 2D, except for the last stage where a noticeable effect of the uniform redistribution is present, resulting in a greater displacement at the surface.

For the last stage the result closest to the field measurements, both in magnitude of displacement and shape of the curve, is the curve obtained from Plaxis 2D.

The displacement curve obtained through the software Cype shows almost no displacement in the first 13 meters of the pile for all stages. 
Measurements obtained from inclinometers are unusual; since that high displacement in early stages is unespected to occur due to that stiffness of piles and working load of anchors were design for a higher condicion of pressure that occurs on the final stage. Tension loads of anchors and rebar frames of piles are designed for the most unfavorable condition, which in this case is $\mathbf{2 7 . 5} \mathrm{m}$ of free height. Therefore, the expected behavior of the system is that tension loads of anchors control displacements in the early stages of the excavation and allow greater displacement in the last stage, because a significant percentage of active pressure is being used for final designing.

Seismic effects can cause major displacement in retaining structures because the increment on the pressure against the wall and the permanent deformation that occurs in anchors due to the ductility of the steel elements (INN, 2010). In this case the aftershocks that occurred in the early stages of the excavation should not cause displacement as the ones registered in measuring, mainly because the free height was low, so the magnitude of pressure was also low.

In the area of instrumented piles, anchors were not installed in the piles as these could not be perforated because of the inclinometers placed. Thus, anchors were installed alongside the piles and it was required to use a steel beam to transfer the load from the anchors to the piles. This could have generated some special condition in the behavior of the pile.

Another reason to explain the high level of displacement recorded in the upper area of the pile could be related to the influence of building construction activities (Clough \& O'Rourke, 1990). In this case it is attributable to vibrations generated during excavation in front of the pile and during the installation of the first anchor. However, it is not possible to discard errors in measurements or interpretation of the field data. One of the main sources of error is the repeatability of reading measurement that increase with the length of the casing (Dunnicliff, 1988), then it is important to have several readings for a same excavation condition in order to discart the ones that out of the repeatability accuracy of the used equipment.

The model performed in the software Plaxis $2 \mathrm{D}$ is the one providing the curve that best fits the results measured at the site for the last stage.

The model performed in the software CYPE shows low displacement in the first half of the pile. The reason for this is that the force-deformation system used by the program does not consider redistribution, so the earth pressure values increase with depth.

Regarding the model performed in the software GGU-Retain, when considering a uniform distribution of the pressure as indicated in the Chilean Norm NCh3206 (INN, 2010), higher loads will be obtained in the area closest to pile's head. In this case it becomes noticeable in the last stage, in which the pressure value is high, and where the largest displacement in the head is achieved with the model performed in GGU-Retain.

The displacement in opposite direction to the excavation or null displacement obtained on the numerical models for stages earlier than final, in particular on the upper part of the pile, are explained because first and second lines of anchors have a charge equivalent to the service load of final stage, then total force against the pile is higher than active pressupe, even higher than at rest pressure for earlier stages, then its normal to have opposite displacement associated to partial development of passive pressure or null displacement associated to at-rest pressure.

In other design codes as EAB (DGGT, 2014), various redistributions of pressure are delivered, depending on the type of wall, number of anchor levels and their location. In the case of three levels of anchors, redistribution is triangular at the top length of the pile, starting from zero. Therefore, the results will be very different for the top part of the wall depending on the type of design code to be used (distribution of pressure used).

Abramson, L.W., Lee, T.S., Sharma, S., \& Boyce, G.M. (2002). Slope stability and stabilization methods. New York, NY: John Wiley \& Sons.

Brinkgreve, R.B.J. (2014). Material model manual. Delft, Netherlands: Delft University of Technology \& Plaxis BV.

Candogan, A. (2009). The art and practice of foundation engineering. Estambul, Turkey: Ali Candogan.

Civilserve Gmbh. (2007). GGU-Retain: Manual de usuario. Steinfeld, Germany: Civilserve Gmbh. 
Clough, G.W., \& O'Rourke, T.D. (1990). Construction induced movement of in-situ walls. In P. Lambe \& L. Hansen (eds.). Design and performance of earth retaining structures (pp. 439-470). Ithaca, NY: ASCE.

Coduto, D. P., Yeung M. R. \& Kitch, W. A. (2011). Geotechnical engineering: Principles and practices. New York, NY: Pearson Education.

Cype Ingenieros S.A. (n.d). Elementos de contención: Cálculo de empujes. Alicante, Spain: Cype Ingenieros S.A.

DGGT, German Geotechnical Society (2014). Recommendations on excavations EAB. Berlin, Germany: Ernst \& Sohn.

Dunnicliff, J. (1988). Geotechnical Instrumentation for Monitoring Field Performance. New York, NY: John Wiley \& Sons.

FCFM, Facultad de Ciencias Físicas y Matemáticas (2011). Especial Beauchef 851. Beauchef Magazine. Retrieved from http://ingenieria.uchile.cl/publicaciones/89717/especial-beauchef-851

INN (2010). NCh 3206 Of. 2010: Geotecnia-excavaciones, entibaciones y socalzados - requisitos. Santiago, Chile: Instituto Nacional de Normalización.

Kempfert, H., Dieter, K., \& Smoltczyk, U. (2003). Pile foundations. In U. Smoltczyk (ed.). Geotechnical engineering handbook Volume 3: Elements and structures (pp. 83-227). Berlin, Germany: Ernst \& Sohn.

Ortigosa, P., \& Hidalgo, E. (1997). Estabilidad de excavaciones en la línea 5 del Metro de Santiago. Paper presented at the IV Congreso Chileno de Ingeniería Geotécnica of Universidad Federico Santa María, Chile.

Ortigosa, P., \& Kort, I. (1997). Predicción de asentamientos en la grava de Santiago. Paper presented at the IV Congreso Chileno de Ingeniería Geotécnica of Universidad Federico Santa María, Chile.

Ostermayer, H., \& Barley, T. (2003). Ground anchors. In U. Smoltczyk (ed.). Geotechnical engineering handbook Volume 2: Procedures (pp. 169-219). Berlin, Germany: Ernst \& Sohn.

Pilotes Terratest (n.d.a). Proyecto: Ampliación clínica Santa María. Retrieved from: http://www.terratest.cl/documentos/FT-06131-01-rev.1.pdf

Pilotes Terratest (n.d.b). Proyecto: Escuela de ingeniería Beaucheff Poniente. Retrieved from: http://www.terratest.cl/documentos/FT-09132-01rev.1.pdf

Pilotes Terratest (2011). Presentación instrumentación de entibación. Unpublished power point, Pilotes Terratest, Santiago, Chile.

Puller, M. (2003). Deep excavations: A practical manual. London, England: Thomas Telford Publishing.

Raddatz, D., Suazo, G. \& Taiba, O. (2016). Strut reaction forces on a diaphragm wall: Comparison of numerical models, traditional methods and field measurements. Revista de La Construcción, 15(2), 37-45.

Rozic, M. (2012). Modelación e instrumentación de las pilas de entibación del proyecto Beauchef Poniente. (Master's thesis). Universidad de Chile, Santiago, Chile.

Saez, E. \& Ledezma, C. (2012). Earthquake-induced pressures on discontinuos piling support on Santiago gravel. Soil Dynamics and Earthquake Engineering, 41, 72-83.

Seed, H.B. \& Whitman, R.V. (1970). Design of earth retaining structures for dynamic loads. In ASCE, Lateral stresses in ground and design of earthretaining structures (pp. 103-147). New York, NY: ASCE.

Terzaghi, K., Peck, R. B. \& Mesri, G. (1996). Soil mechanics in engineering practice. New York, NY: John Wiley \& Sons.

Towhata, I. (2008). Geotechnical earthquake engineering. Berlin, Germany: Springer.

Tsui, Y., \& Clough, G. W. (1974). Plane strain approximations in finite element analyses of temporary walls. In ASCE, Proceedings of analysis and design in geotechnical engineering (Vol. 1, pp. 173-198). Austin, TX: ASCE.

Weissenbach, A., Hettler, A., \& Simpson, B. (2003). Stability of excavations. In U. Smoltczyk (Ed.), Geotechnical engineering handbook, Volume 3: Elements and structures (pp. 273-407). Berlin, Germany: Ernst \& Sohn. 